\title{
Aerosol Generation and Identification for Model Studies of Particle-Lung Interactions
}

\author{
Dorota Kondej \\ Department of Chemical and Aerosol Hazards, Central Institute for Labour Protection \\ - National Research Institute (CIOP-PIB), Poland
}

\section{Tomasz R. Sosnowski}

\begin{abstract}
Faculty of Chemical and Process Engineering, Warsaw University of Technology, Warsaw, Poland
\end{abstract}

This article discusses the idea and set-up of a laboratory system for generating reproducible concentrated occupational aerosols containing metal compounds. Dust representatives for 2 metal-machining workstations (an electric grinder and an electric disc cutter) were released from a fluidized-bed generator, and then sampled and compared in respect to concentration, particle size distribution, particle morphology and the content of metal elements ( $\mathrm{Fe}, \mathrm{Al}, \mathrm{Cu}, \mathrm{Mn}, \mathrm{Cr}, \mathrm{Ni}, \mathrm{Pb}, \mathrm{Zn}, \mathrm{Mg}$ ). The results indicate the presence of a significant number of irregularly-shaped respirable particles. Those particles contained mainly $\mathrm{Fe}$ and $\mathrm{Al}$, and their composition was shown to depend on particle size. The proposed system of aerosol generation and collection can be used in studies of interactions between airborne particles and a model lung surfactant.

industrial aerosols generation concentration size distribution metal elements

\section{INTRODUCTION}

Metals and their compounds are a significant group of hazardous agents in an occupational environment [1]. Over 270000 people work in the manufacturing of metal products in Poland [2]. In industrial conditions workers are most often exposed to metals and their compounds in the form of dust emitted during mechanical processing of metal accessories. Workers' long-term exposure to such dust can induce pathological disorders of the respiratory system [3, 4]. The health effects depend on the chemical composition, mass concentration, size distribution and morphology of particles suspended in workplace air [5]. The aerodynamic size of the particles is a particularly important parameter. It indirectly indicates the regions of the respiratory system where the particles are most probably deposited. Large particles with high inertia are usually deposited in the upper parts of the respiratory tract. Smaller particles inhaled with the air more easily penetrate bronchi and deep lungs, where they are deposited mainly as a result of sedimentation and diffusion. Because of their large surface area, bronchioli and pulmonary alveoli are a significant part of the respiratory system, where the accumulation of inhaled deposits can lead to serious lung disorders such as pneumoconiosis, emphysema and cancers $[6,7]$.

Lung surfactant (LS) present mainly in the bronchiolo-alveolar region is essential for the proper functioning of the respiratory system $[8,9,10]$. It is the first barrier that separates the air inhaled into the alveoli from the lung tissue with pulmonary capillaries. LS is a highly active surface material, 
which through the adsorption at the air-liquid interface of alveolar lining, influences the value of the alveolar surface tension during the breathing cycle. By reducing surface tension, LS stabilizes the alveoli and prevents their collapse during the cycles of lung expansion and compression. LS is also involved in lung defense against inhaled aerosols. All functions of LS are strictly related to its biophysical activity, which is demonstrated by the low value of surface tension at maximum surface compression and by the noticeable loop of surface tension hysteresis during area oscillation (breathing) [11]. External agents such as solid particles deposited at the alveolar surface can change the surface activity of LS. This is reflected by changes in the value of surface tension and the shape of the hysteresis loop. A physicochemical examination of the dust-surfactant system can be a basis for evaluating the interaction of aerosols containing metals and their compounds with LS, and for identifying health hazards posed by such substances in the working environment.

The aim of this study was to develop and confirm the suitability of a laboratory method of generating and identifying aerosols which could represent metal-containing dust produced in occupational conditions. The developed system could be used in the future as a reproducible source of aerosols for in vitro studies of the effect of dust particles on the properties of LS. This type of information is required in assessing the potential role of inhalation-induced surfactant inactivation in the development of occupational diseases of the respiratory system.

\section{METHODS}

\subsection{Raw Material}

The material used for aerosol generation in the laboratory set-up was obtained from the metallic swarf collected in the waste-trays of an electric grinder (EG) and an electric disc cutter (EDC) in the machine shop of the Faculty of Chemical and Process Engineering at the Warsaw University of Technology, Poland. Each material was collected separately.

\subsection{Aerosol Generation}

The system was based on aerosol particle elutriation from a fluidized-bed [12]. The 180-mm long glass column with an internal diameter of $40 \mathrm{~mm}$ was periodically fed with metallic swarf. The fluidization process driven

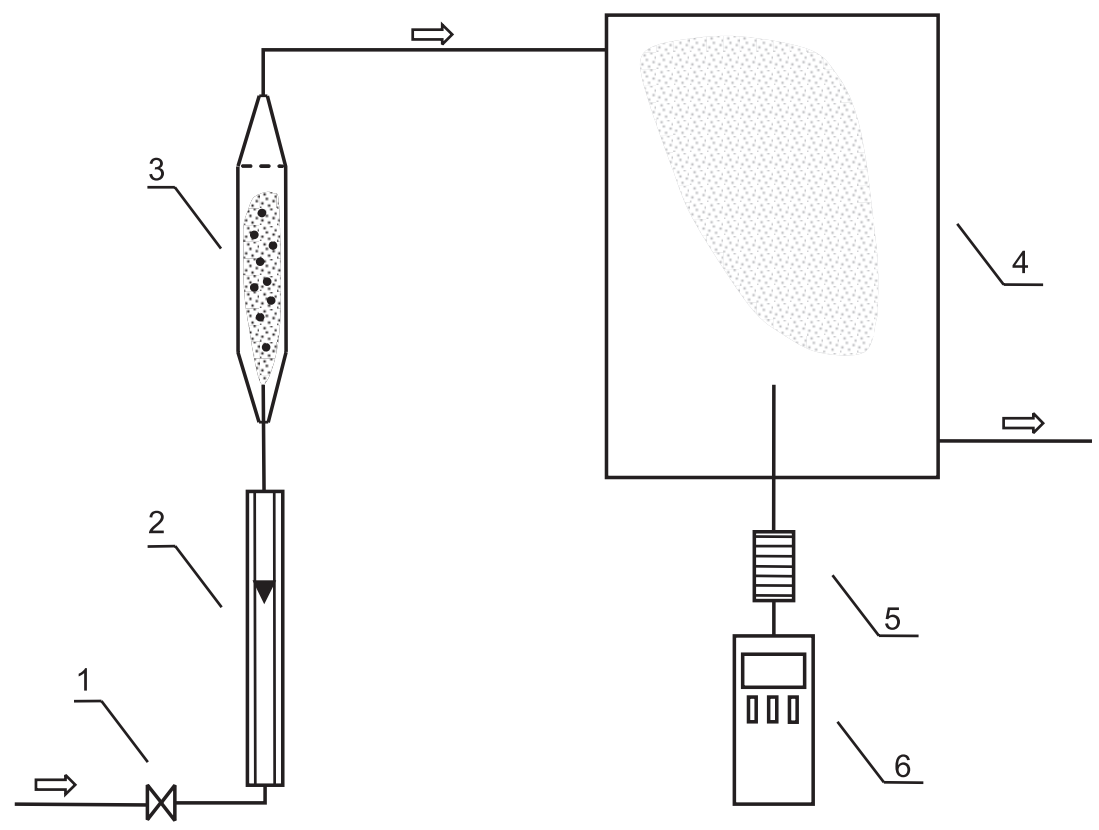

Figure 1. Aerosol generation and sampling system. Notes. 1-valve, 2-flowmeter, 3-fluidized-bed aerosol generator, 4-retention chamber, 5-Sioutas personal cascade impactor sampler (SKC, USA), 6-Leland legacy sample pump (SKC, USA). 
by the airflow supplied from the bottom of the column was facilitated by 3-mm polypropylene pellets which were retained in the column with the mesh mounted at the aerosol outflow at the top of the column. The emitted dust was directed into the retention chamber, from which the aerosol was sampled with a Sioutas personal cascade impactor sampler (PCIS; SKC, USA). The aerosol was drawn through the PCIS with a Leland legacy sample pump (SKC, USA) operated at the flow rate of $0.009 \mathrm{~m}^{3} / \mathrm{min}$. Figure 1 illustrates the set-up of the generating and sampling system. The system was operated semicontinuously for $2 \mathrm{~h}$ with gradual refilling of raw particulate material. Six independent runs of aerosol generation and sampling were done for each type of metallic material.

\subsection{Aerosol Size and Morphology}

The PCIS collected the aerosol in five size ranges: $<0.25, \quad 0.25-0.50,0.5-1.0, \quad 1.0-2.5$, and 2.5-10.0 $\mu \mathrm{m}$; particle size distribution (PSD) was evaluated gravimetrically. PTFE (polytetrafluoroethylene) filters from all impactor stages were conditioned in a desiccating chamber (Bohlender, Germany) for $24 \mathrm{~h}$ before the weighing. Both the size and the morphology of particles collected on impactor stages were also inspected under a Quanta 200 scanning electron microscope (SEM; Fei, The Netherlands).

\subsection{Chemical Analysis of Aerosol Particles}

Particles collected in the PCIS were analyzed within each size range for the contents of metal elements; atomic absorption spectrometry was used. The particles were washed off the filters with a mixture of concentrated nitric acid and water $(1: 2, \mathrm{v} / \mathrm{v})$, and then nitric acid $(1 \mathrm{~mol} / \mathrm{l})$ in an ultrasonic bath $(30 \mathrm{~min})$. Depending on the concentration range $(\mathrm{ng} / \mathrm{ml}$ or $\mu \mathrm{g} / \mathrm{ml})$ either SpectrAA 880 (Varian, USA) with Zeeman background correction or Solaar M (Thermo Electron, USA) with an air-acetylene flame were used, respectively. The contents of iron $(\mathrm{Fe})$, zinc $(\mathrm{Zn})$, manganese $(\mathrm{Mn})$, chromium $(\mathrm{Cr})$, magnesium $(\mathrm{Mg})$, aluminum $(\mathrm{Al})$, lead $(\mathrm{Pb})$, nickel $(\mathrm{Ni})$, and copper $(\mathrm{Cu})$ were determined.
The detection limits were $11.6 \mu \mathrm{g} / \mathrm{m}^{3}$ for $\mathrm{Fe}$, $2.3 \mu \mathrm{g} / \mathrm{m}^{3}$ for $\mathrm{Zn}, 3.5 \mu \mathrm{g} / \mathrm{m}^{3}$ for $\mathrm{Mn}, 6.0 \mu \mathrm{g} / \mathrm{m}^{3}$ for $\mathrm{Cr}, 2.3 \mu \mathrm{g} / \mathrm{m}^{3}$ for $\mathrm{Mg}, 0.2 \mu \mathrm{g} / \mathrm{m}^{3}$ for $\mathrm{Al}, 0.2 \mu \mathrm{g} / \mathrm{m}^{3}$ for $\mathrm{Pb}, 0.2 \mu \mathrm{g} / \mathrm{m}^{3}$ for $\mathrm{Ni}$, and $0.2 \mu \mathrm{g} / \mathrm{m}^{3}$ for $\mathrm{Cu}$.

\subsection{A Method for Studying Particle-LS Interactions}

The method proposed here for assessing dynamic surface-active properties of LS after contact with particles is based on programmed pulsations of a small air bubble in a solution of purified cow LS (Survanta, Abbott Laboratories, UK). During such studies, dynamic surface tension is recorded, indicating during consecutive compressionexpansion cycles the well-known hysteresis loop [13, 14]. To determine the influence of dust particles on LS activity, it is proposed that the particles collected on each impactor filter will be washed off in an ultrasonic bath with a known amount of physiological salt solution $(0.9 \% \mathrm{NaCl}$ aq). Then the resulting suspension with the known particle mass will be mixed with an adjusted amount of LS to obtain the desired dilution of the surfactant (the effective concentration of the particles with the known size will be recalculated). Such a mixture will be thermostated for $30 \mathrm{~min}$ (at $37{ }^{\circ} \mathrm{C}$ ) before the surface tension analysis which will be conducted with a pulsating bubble surfactometer (Electronetics, USA) [15]. It is expected that from a systematic comparison of the surface tensionbubble area relationships measured during bubble pulsations in pure and particle-contaminated LS material, a physicochemical surfactant inactivation may be detected. LS inactivation effects might be expected on the basis of earlier studies on interactions of soot particles with surfactant [16], the results of which could be explained, e.g., with a preferential adsorption of LS molecules on dust particles [17].

\section{RESULTS}

\subsection{Aerosol Concentration, PSD and Morphology}

Impactor analysis showed that the total concentration of the aerosol $\left(\mathrm{PM}_{10}\right)$ emitted 
from the developed laboratory system fed by EG and EDC swarf was in the range of 2.8-4.4 ( $M$ 3.6) for EG and $3.5-5.5 \mathrm{mg} / \mathrm{m}^{3}$ ( $M$ 4.3) for EDC. These values were higher than the usual concentrations in the workplace [18]. However, a high concentration of the aerosol is an advantage of this method since the time it takes to collect particles is shorter. The low variation of aerosol concentration is also an advantage for further quantitative studies related to its influence on LS function.
Figure 2 illustrates a comparison of size distribution of aerosol particles from different sources. The PSD was in both cases similar with the predominant mass of particles in two size ranges: $2.5-10.0(\sim 45 \%)$ and $1.0-2.5 \mu \mathrm{m}(\sim 30 \%)$. There was a difference in the submicron range as the EG aerosol contained more ultrafine particles $(<0.25 \mu \mathrm{m})$ than the EDC one. SEM photographs in Figure 3 indicate that particles in both aerosols are sharp-edged and irregularly shaped. Such particle morphology suggests that the area-

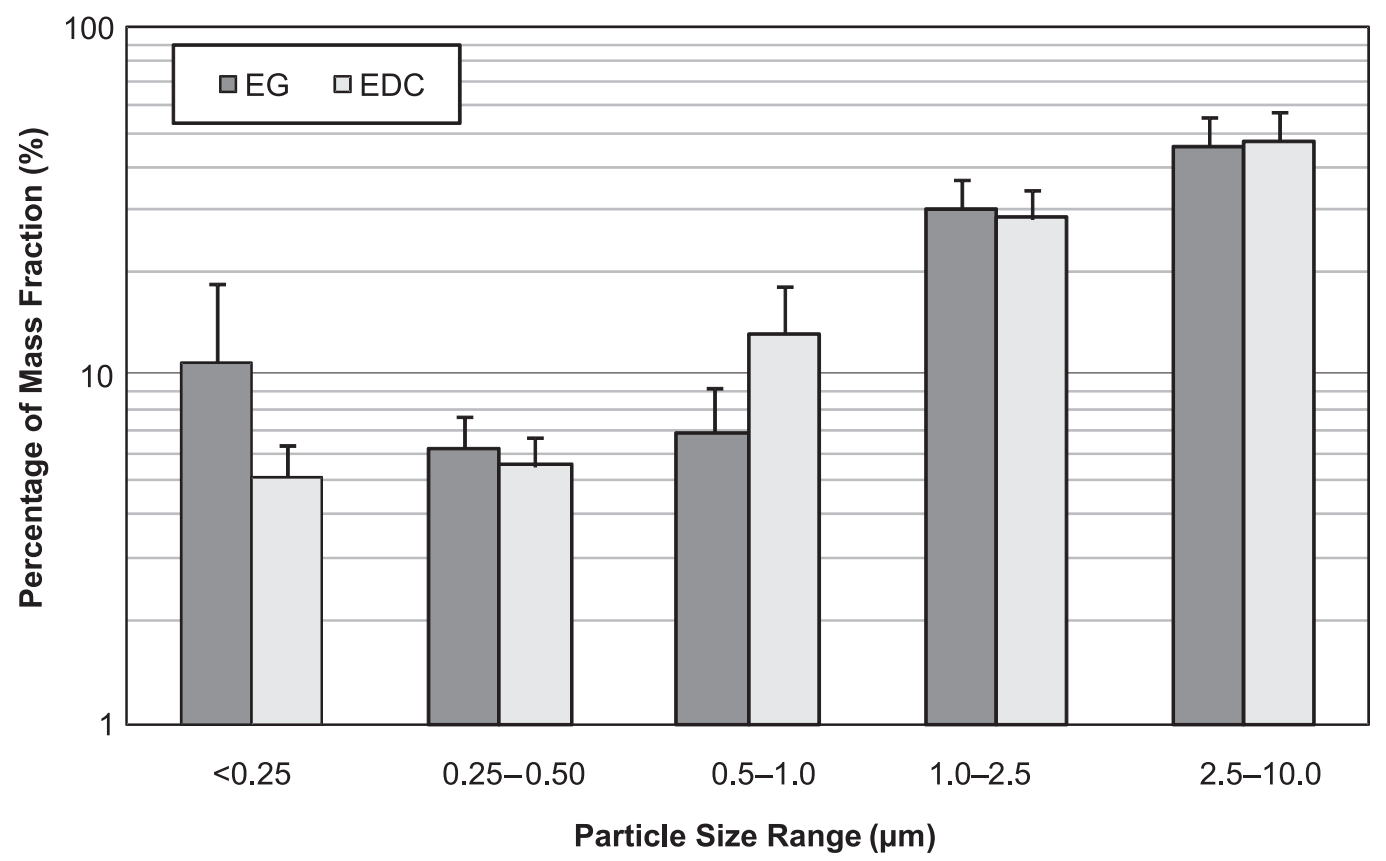

Figure 2. Particle size distribution. Notes. EG-electric grinder, EDC-electric disc cutter; error bars represent standard deviations.

(a)

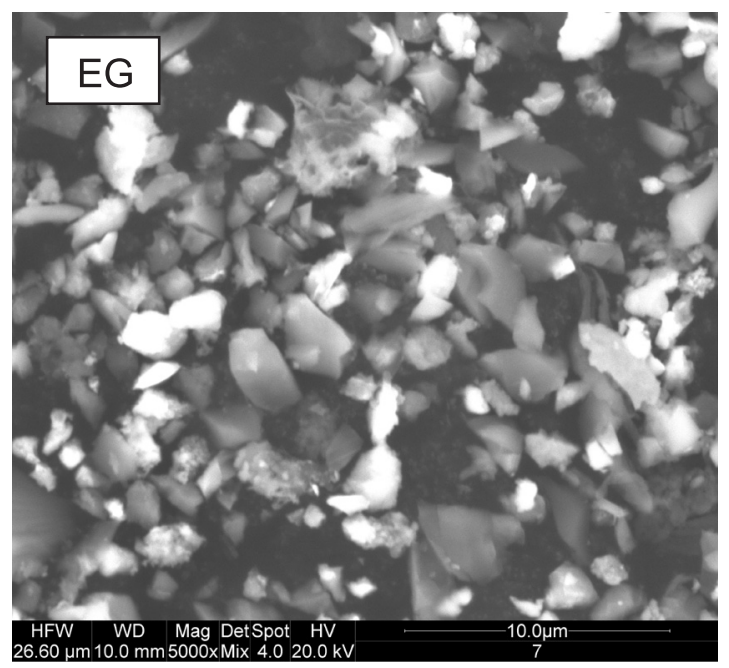

(b)

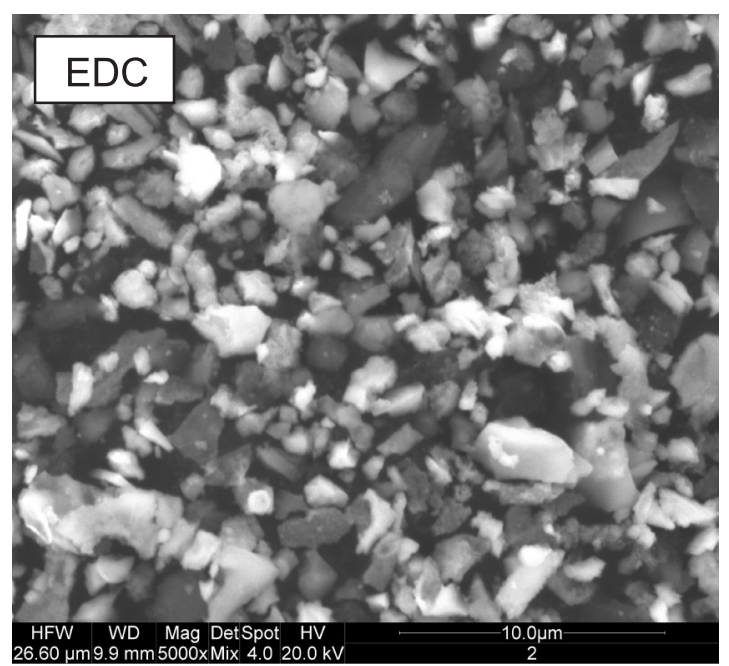

Figure 3. Particle morphology (size range 1.0-2.5 $\mu \mathrm{m}$ ): (a) electric grinder (EG), (b) electric disc cutter (EDC). 
to-volume ratio is higher than for smooth and spherical particles. Therefore, any interactions inside the lungs which depend on this ratio (e.g., postulated sorption-related inactivation of LS) will be more severe.

\subsection{Chemical (Elemental) Analysis}

The samples collected from both types of dust mainly contained $\mathrm{Fe}$, followed by $\mathrm{Al}$ (Tables 1-2). These facts simply reflect the types of materials usually machined with EG and EDC in the machine shop, i.e., steel and aluminum alloys.

Figures 4-5 illustrate the elemental composition of aerosol particles within three size ranges:
$<1,1.0-2.5$, and $2.5-10.0 \mu \mathrm{m}$ obtained for both types of dusts. This comparison shows that the composition of dust varies within different size ranges. For example, in EG dust $\sim 60 \%$ of $\mathrm{Fe}$ was in particles with the size of $2.5-10.0 \mu \mathrm{m}$ and $\sim 15 \%$ in submicron particles. At the same time the distribution of $\mathrm{Cu}$ was significantly different: almost $74 \%$ was in the $2.5-10.0 \mu \mathrm{m}$ range and $<6 \%$ in submicron particles. The observed dissimilarity is most probably related to different mechanical properties (e.g., hardness, plasticity, brittleness) of the materials machined with EG. In EDC dusts, variations like that were also present; however, they were less distinct.

TABLE 1. Metal Concentrations $(M \pm S D)$ in an Electric Grinder Aerosol

\begin{tabular}{|c|c|c|c|c|c|c|c|c|c|}
\hline \multirow{2}{*}{$\begin{array}{l}\text { Particle Size } \\
(\mu \mathrm{m})\end{array}$} & \multicolumn{9}{|c|}{ Concentration $\left(\mu \mathrm{g} / \mathrm{m}^{3}\right)$} \\
\hline & $\mathrm{Fe}$ & Zn & Mn & $\mathrm{Cr}$ & Mg & Al & $\mathbf{P b}$ & $\mathbf{N i}$ & $\mathrm{Cu}$ \\
\hline$<0.25$ & $\begin{array}{r}164.5 \\
\pm 10.9\end{array}$ & $\begin{array}{r}11.9 \\
\pm 0.5\end{array}$ & BDL & BDL & $\begin{array}{c}3.8 \\
\pm 0.1\end{array}$ & $\begin{array}{r}16.2 \\
\pm 1.0\end{array}$ & $\begin{array}{c}8.5 \\
+1.8\end{array}$ & $\begin{array}{c}3.6 \\
\pm 0.7\end{array}$ & $\begin{array}{c}2.8 \\
\pm 0.6\end{array}$ \\
\hline $0.25-0.50$ & $\begin{array}{r}44.2 \\
\pm 1.1\end{array}$ & BDL & BDL & BDL & $\begin{array}{c}4.0 \\
\pm 1.0\end{array}$ & $\begin{array}{r}16.6 \\
\pm 0.8\end{array}$ & BDL & $\begin{array}{c}0.8 \\
\pm 0.1\end{array}$ & $\begin{array}{c}1.5 \\
\pm 0.1\end{array}$ \\
\hline $0.50-1.00$ & $\begin{array}{r}141.3 \\
\pm 16.7\end{array}$ & $\begin{array}{r}12.0 \\
\pm 2.7\end{array}$ & BDL & BDL & $\begin{array}{r}13.3 \\
\pm 2.8\end{array}$ & $\begin{array}{l}33.4 \\
\pm 4.7\end{array}$ & $\begin{array}{c}0.5 \\
\pm 0.1\end{array}$ & $\begin{array}{c}2.5 \\
\pm 0.2\end{array}$ & $\begin{array}{c}5.1 \\
\pm 1.8\end{array}$ \\
\hline $1.00-2.50$ & $\begin{array}{r}538.2 \\
\pm 97.6\end{array}$ & $\begin{array}{l}36.0 \\
\pm 4.6\end{array}$ & $\begin{array}{c}3.6 \\
\pm 0.6\end{array}$ & $\begin{array}{c}8.5 \\
\pm 1.2\end{array}$ & $\begin{array}{l}30.7 \\
\pm 4.5\end{array}$ & $\begin{array}{r}113.5 \\
\pm 13.4\end{array}$ & $\begin{array}{c}5.1 \\
\pm 1.1\end{array}$ & $\begin{array}{c}9.3 \\
\pm 1.1\end{array}$ & $\begin{array}{l}28.0 \\
\pm 3.3\end{array}$ \\
\hline $2.50-10.0$ & $\begin{array}{r}1444.9 \\
\pm 60.5\end{array}$ & $\begin{array}{l}137.7 \\
\pm 8.7\end{array}$ & $\begin{array}{l}28.2 \\
\pm 1.1\end{array}$ & $\begin{array}{r}16.1 \\
\pm 1.2\end{array}$ & $\begin{array}{l}45.6 \\
\pm 5.8\end{array}$ & $\begin{array}{r}168.7 \\
\pm 12.6\end{array}$ & $\begin{array}{r}16.1 \\
\pm 1.2\end{array}$ & $\begin{array}{l}20.3 \\
\pm 1.7\end{array}$ & $\begin{array}{r}98.0 \\
\pm 4.2\end{array}$ \\
\hline total & $\begin{array}{r}2333.1 \\
\pm 118.1\end{array}$ & $\begin{array}{r}197.6 \\
\pm 12.3\end{array}$ & $\begin{array}{r}34.1 \\
\pm 1.6\end{array}$ & $\begin{array}{r}24.6 \\
\pm 2.5\end{array}$ & $\begin{array}{c}97.4 \\
\pm 10.1\end{array}$ & $\begin{array}{l}348.4 \\
\pm 20.1\end{array}$ & $\begin{array}{r}30.3 \\
\pm 3.5\end{array}$ & $\begin{array}{r}36.5 \\
\pm 2.5\end{array}$ & $\begin{array}{c}135.4 \\
\pm 6.4\end{array}$ \\
\hline
\end{tabular}

Notes. Fe—iron, $\mathrm{Zn}$-zinc, Mn—manganese, $\mathrm{Cr}$-chromium, $\mathrm{Mg}$-magnesium, $\mathrm{Al}$-aluminum, $\mathrm{Pb}$-lead, $\mathrm{Ni}$ nickel, $\mathrm{Cu}$-copper; BDL-below detection limit.

TABLE 2. Metal Concentrations $(M \pm S D)$ in an Electric Disc Cutter Aerosol

\begin{tabular}{|c|c|c|c|c|c|c|c|c|c|}
\hline \multirow{2}{*}{$\begin{array}{l}\text { Particle Size } \\
(\mu \mathrm{m})\end{array}$} & \multicolumn{9}{|c|}{ Concentration $\left(\mu \mathrm{g} / \mathrm{m}^{3}\right)$} \\
\hline & Fe & $\mathrm{Zn}$ & Mn & $\mathrm{Cr}$ & Mg & Al & $\mathbf{P b}$ & $\mathrm{Ni}$ & $\mathrm{Cu}$ \\
\hline$<0.25$ & $\begin{array}{r}303.1 \\
\pm 23.5\end{array}$ & $\begin{array}{r}24.2 \\
\pm 4.8\end{array}$ & $\begin{array}{r}10.1 \\
\pm 1.3\end{array}$ & BDL & $\begin{array}{r}10.6 \\
\pm 1.3\end{array}$ & $\begin{array}{r}69.4 \\
\pm 8.2\end{array}$ & $\begin{array}{r}1.9 \\
\pm 0.4\end{array}$ & $\begin{array}{r}20.8 \\
\pm 4.3\end{array}$ & $\begin{array}{r}20.9 \\
\pm 4.8\end{array}$ \\
\hline $0.25-0.50$ & $\begin{array}{r}141.9 \\
\pm 29.9\end{array}$ & $\begin{array}{r}7.2 \\
\pm 1.5\end{array}$ & $\begin{array}{r}4.6 \\
+0.8\end{array}$ & $\begin{array}{r}19.2 \\
\pm 4.1\end{array}$ & $\begin{array}{r}3.2 \\
\pm 0.7\end{array}$ & $\begin{array}{r}16.4 \\
\pm 3.5\end{array}$ & $\begin{array}{r}0.8 \\
\pm 0.2\end{array}$ & $\begin{array}{r}2.8 \\
\pm 0.6\end{array}$ & $\begin{array}{r}4.6 \\
+1.0\end{array}$ \\
\hline $0.50-1.00$ & $\begin{array}{r}207.1 \\
\pm 76.2\end{array}$ & $\begin{array}{r}30.8 \\
\pm 5.4\end{array}$ & $\begin{array}{r}8.2 \\
\pm 0.9\end{array}$ & $\begin{array}{l}30.5 \\
\pm 5.5\end{array}$ & $\begin{array}{r}10.3 \\
\pm 1.3\end{array}$ & $\begin{array}{r}51.8 \\
\pm 7.3\end{array}$ & $\begin{array}{r}1.7 \\
\pm 0.3\end{array}$ & $\begin{array}{r}16.4 \\
\pm 2.0\end{array}$ & $\begin{array}{r}47.1 \\
\pm 5.7\end{array}$ \\
\hline $1.00-2.50$ & $\begin{array}{r}697.4 \\
\pm 78.4\end{array}$ & $\begin{array}{r}60.9 \\
\pm 8.0\end{array}$ & $\begin{array}{r}28.5 \\
\pm 5.7\end{array}$ & $\begin{array}{l}41.1 \\
\pm 8.4\end{array}$ & $\begin{array}{r}16.3 \\
\pm 3.3\end{array}$ & $\begin{array}{r}182.6 \\
\pm 36.8\end{array}$ & $\begin{array}{r}4.3 \\
\pm 0.9\end{array}$ & $\begin{array}{r}68.6 \\
\pm 13.8\end{array}$ & $\begin{array}{r}49.5 \\
\pm 9.0\end{array}$ \\
\hline $2.50-10.0$ & $\begin{array}{r}1206.3 \\
\pm 253.1\end{array}$ & $\begin{array}{r}82.3 \\
\pm 17.3\end{array}$ & $\begin{array}{r}40.1 \\
\pm 8.4\end{array}$ & $\begin{array}{c}49.5 \\
\pm 10.4\end{array}$ & $\begin{array}{r}19.7 \\
\pm 4.1\end{array}$ & $\begin{array}{r}212.5 \\
\pm 44.6\end{array}$ & $\begin{array}{r}9.5 \\
\pm 2.0\end{array}$ & $\begin{array}{r}122.6 \\
\pm 25.7\end{array}$ & $\begin{array}{r}65.1 \\
\pm 13.7\end{array}$ \\
\hline total & $\begin{array}{r}2555.7 \\
\pm 497.7\end{array}$ & $\begin{array}{r}205.4 \\
\pm 38.8\end{array}$ & $\begin{array}{r}90.9 \\
\pm 17.3\end{array}$ & $\begin{array}{r}140.7 \\
\pm 26.9\end{array}$ & $\begin{array}{r}60.1 \\
\pm 9.3\end{array}$ & $\begin{array}{r}532.7 \\
\pm 56.6\end{array}$ & $\begin{array}{r}18.0 \\
\pm 3.5\end{array}$ & $\begin{array}{r}231.1 \\
\pm 44.2\end{array}$ & $\begin{array}{r}187.1 \\
\pm 34.0\end{array}$ \\
\hline
\end{tabular}

Notes. Fe-iron, $\mathrm{Zn}$-zinc, Mn—manganese, $\mathrm{Cr}$-chromium, Mg-magnesium, Al—aluminum, $\mathrm{Pb}$-lead, $\mathrm{Ni}$ nickel, $\mathrm{Cu}$-copper; BDL-below detection limit. 


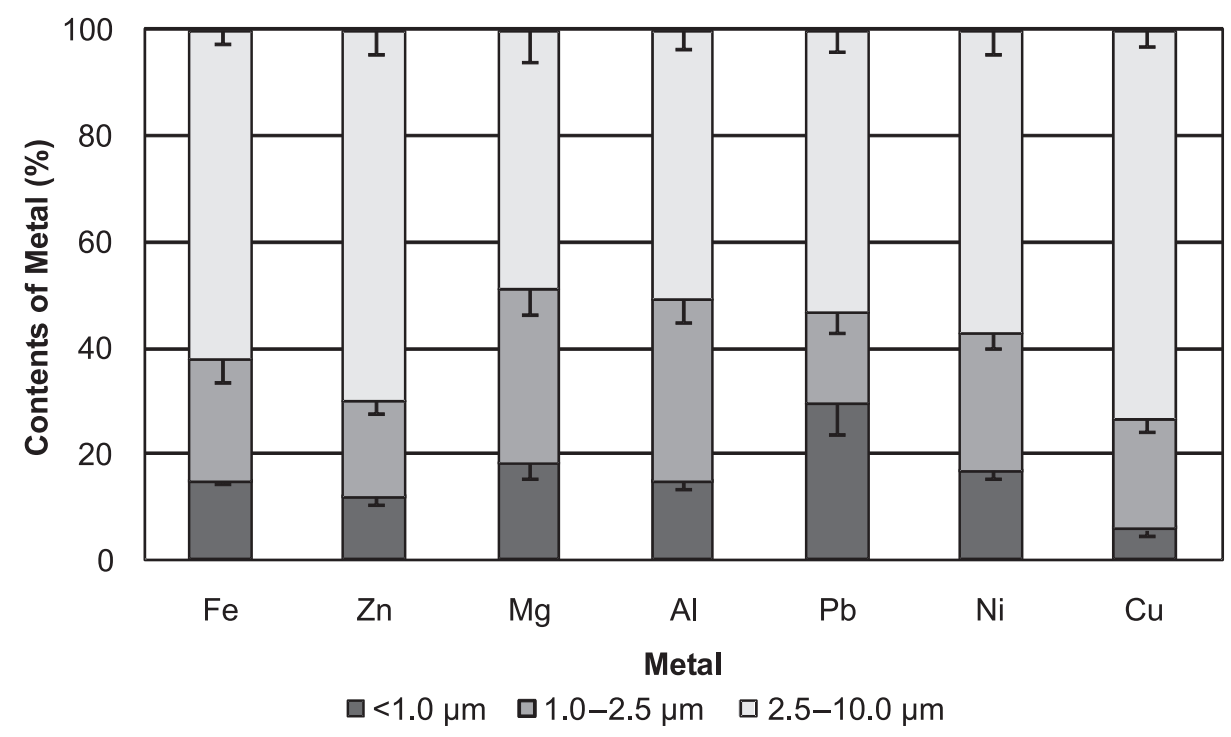

Figure 4. Contents of metal in different size ranges of the electric grinder aerosol. Notes. Fe-iron, $\mathrm{Zn}$-zinc, $\mathrm{Mn}$-manganese, $\mathrm{Cr}$-chromium, $\mathrm{Mg}$ - magnesium, $\mathrm{Al}$-aluminum, $\mathrm{Pb}$-lead, $\mathrm{Ni}$-nickel, $\mathrm{Cu}-$ copper; error bars represent standard deviations.

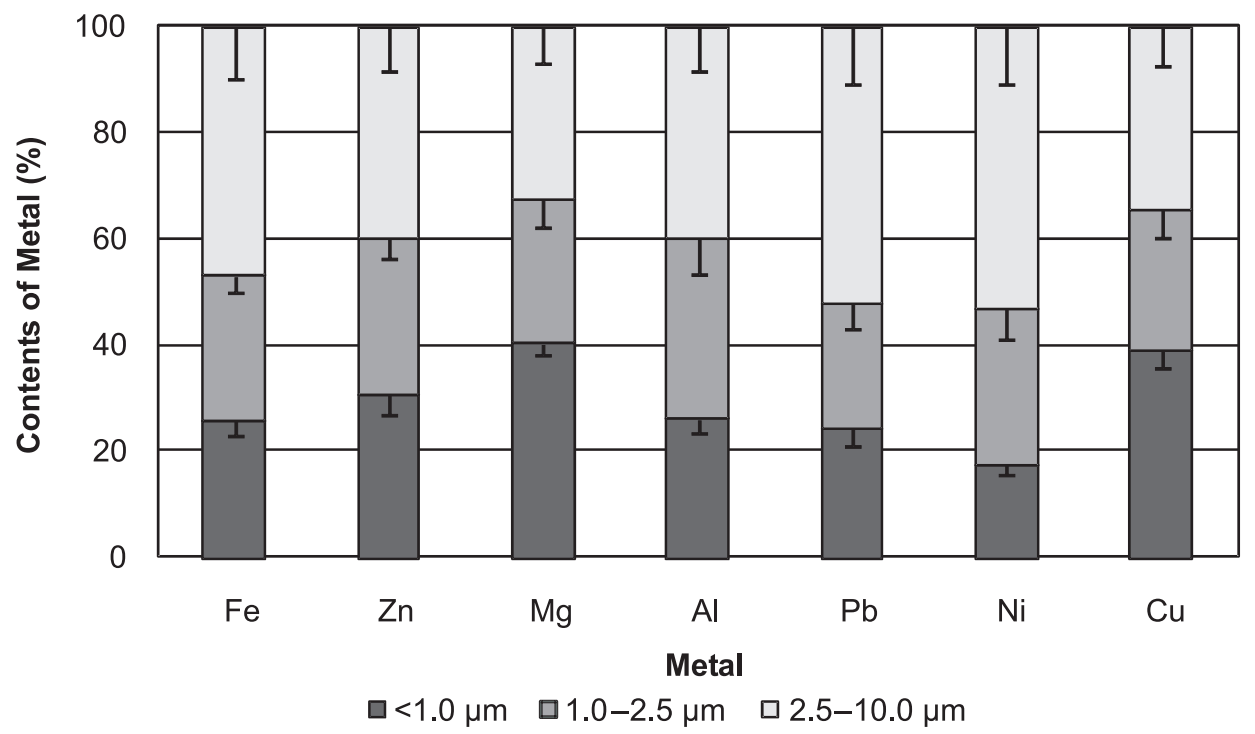

Figure 5. Contents of metal in different size ranges of the electric disc cutter aerosol. Notes. Fe-iron, $\mathrm{Zn}$-zinc, $\mathrm{Mn}$-manganese, $\mathrm{Cr}$-chromium, $\mathrm{Mg}$-magnesium, $\mathrm{Al}$-aluminum, $\mathrm{Pb}$-lead, $\mathrm{Ni}$-nickel, $\mathrm{Cu}-$ copper; error bars represent standard deviations.

\subsection{Preliminary Trials of Particles- Surfactant Interactions}

Samples of model LS after contact with particles collected on the filter (according to the procedure in section 2.5) were examined using the pulsating bubble surfactometer at $37{ }^{\circ} \mathrm{C}$ and bubble oscillation frequency of $12 \mathrm{~min}^{-1}$. Preliminary comparisons of surface tension hysteresis for unexposed and exposed LS showed that hysteresis was lower for exposed LS and the values of surface tension generally increased (Figure 6). These findings indicate that the properties of LS after contact with particles containing metals and their compounds change in a way suggesting at least partial reduction in surface activity. In this way LS exposure to such aerosols may result in impairment of physiological functions related to specific interfacial behavior of LS. Our preliminary results correspond with the recent 


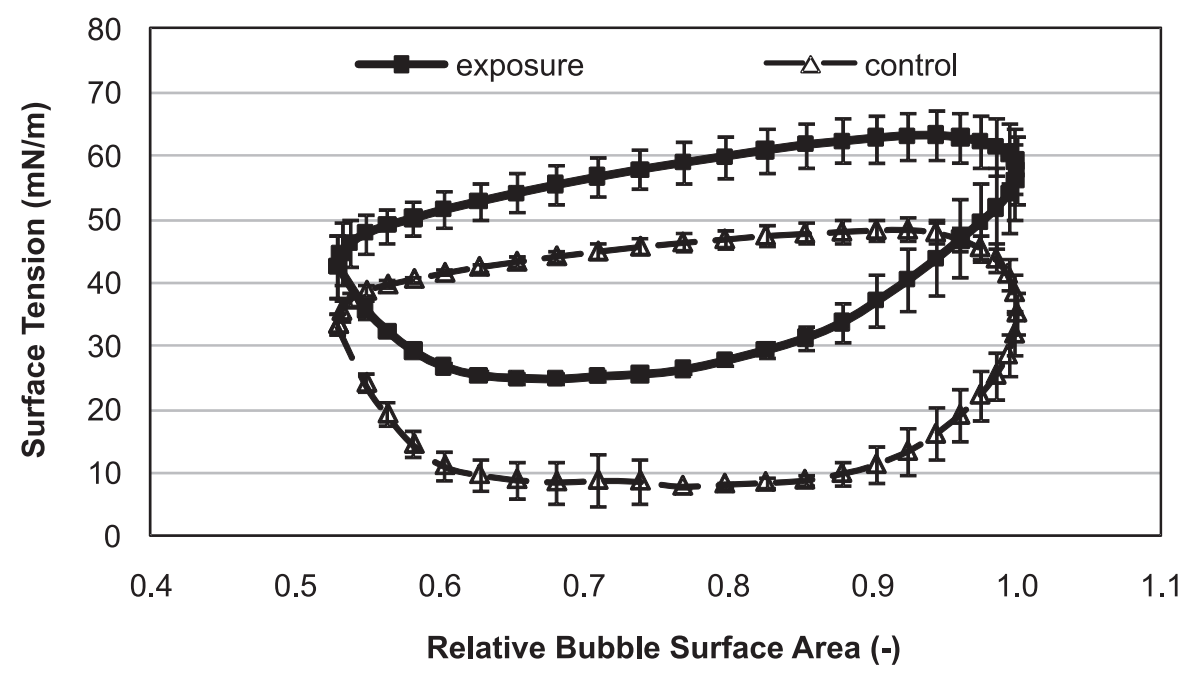

Figure 6. Examples of surface tension hysteresis after contact of lung surfactant with metallic dust particles. Notes. Error bars represent standard deviations.

findings of Bakhsi, Zhao, Smith, et al., who used a captive bubble tensiometer to detect surfactant abnormalities after exposure to gold nanoparticles [19].

\section{DISCUSSION AND CONCLUSIONS}

The methodology and set-up proposed in this paper makes it possible to repeatedly generate highly concentrated aerosols with the overall characteristics (PSD, composition) representative for the working environment of metal machining. The laboratory system can be especially useful in toxicology-related studies that require a quantitative assessment of the effects in respect to the concentration (or dose) of aerosols with controlled characteristics. In vitro evaluation of physicochemical interactions between particles of different size range and LS is an example of such research. The results of ongoing studies will be reported in the near future.

There are several advantages of the proposed method of generating and collecting particles; it makes it possible

- to establish average dust concentration and PSD of any modeled occupational aerosol;

- to determine the elemental composition of a model dust within relatively narrow size ranges (according to impactor resolution);
- to expose the biologically-relevant model system (LS) to airborne contaminants with a preselected particle size.

It was demonstrated that for two types of occupational dust (released from EG and from EDC), PSD was dissimilar in the submicrometer size range only. Looking at the elemental composition of both aerosols, one can note differences in the overall amounts of aluminum, nickel and chromium, which is probably because EDC is more often used in machining steel elements than EG. On the basis of these studies it is also evident that the composition of dust can be different for particles with various size, so the compound-related effects of exposure may be expected to vary with the dust size range. Taking into account that particles with various sizes also exhibit different efficiency of deposition in various lung regions, this lets us conclude that the proposed system of exposure makes it possible to explain more easily both size- and compositiondependent effects. The developed system of aerosol generation and identification is already used in in vitro evaluation of LS inactivation by occupational dusts.

\section{REFERENCES}

1. Gawęda E, Kondej D. Occupational risk assessment to metals in manufacturing processes of metal accessories [abstract]. 
In: XVIII Mendeleev Congress on General and Applied Chemistry. Moscow, Russia: Granitsa; 2007. vol. 3, p. 47.

2. Statistical Yearbook of the Republic of Poland 2007. Warszawa, Poland: Zakład Wydawnictw Statystycznych; 2007. p. 238-45. In Polish.

3. Palmer KT, Ayres JG, Mann J, Burge PS, Coggon D. Exposure to metal fume and infectious pneumonia. Am J Epidemiol. 2003;157: 227-33.

4. Ruediger HW. Hard metal particles and lung disease: coincidence or causality? Respiration. 2000;67:137-8.

5. Warheit DB, Brock WJ, Lee KP, Webb TR, Reed KL. Comparative pulmonary toxicity inhalation and instillation studies with different $\mathrm{TiO}_{2}$ particle formulations: impact of surface treatments on particle toxicity. Toxicol Sci. 2005;88:514-24.

6. Nordberg FG, Fowler BA, Nordberg M, Friberg LT, editors. Handbook on the toxicology of metals. 3rd ed. Burlington, MA, USA: Academic Press; 2007.

7. Rom WN, editor. Environmental \& occupational medicine. 3rd ed. Philadelphia, PA, USA: Lippincott-Raven; 1998.

8. Saxena S. Lung surfactant. The indispensable component of respiratory mechanics. Resonance. 2005;10(8);91-6.

9. Enhorning G. Surfactant in airway disease. Chest. 2008;13:975-80.

10. Wright JR. Pulmonary surfactant: a front line of lung host defense. J Clin Invest. 2003;111:1453-5.

11. Sosnowski TR. Dynamic surface tension as an indicator of lung function in health and disease. Biocyb Biomed Eng. 2003;23:89-98.
12. Kondej D, Sosnowski TR. Laboratory system for metal dusts generation [abstract T09A029P] [pendrive]. In: European Aerosol Conference, Thessaloniki; 2008.

13. Notter RH, Taubold R, Mavis RD. Hysteresis in saturated phospholipid films and its potential relevance for lung surfactant functions in vivo. Exp Lung Res. 1982; 3:109-27.

14. Sosnowski TR, Podgórski A. Assessment of the pulmonary toxicity of inhaled gases and particles with physicochemical methods. International Journal of Occupational Safety and Ergonomics (JOSE). 1999;5:433-49.

15. Enhörning G. Pulsating bubble technique for evaluating pulmonary surfactant. J Appl Physiol. 1977;43:198-203.

16. Sosnowski TR, Gradoń L, Podgórski A. Influence of insoluble aerosol deposits on the surface activity of the pulmonary surfactant: a possible mechanism of alveolar clearance retardation? Aerosol Sci Techn. 2000;32:52-60.

17. Sosnowski TR, Gradoń L, Iskandar F, Okuyama, K. Interaction of deposited aerosol particles with the alveolar liquid layer. In: Gradoń L, Marijnissen J, editors. Optimization of aerosol drug delivery. Dordrecht, The Netherlands: Kluwer Academic; 2008. p. 205-16.

18. Jankowska E, Kondej D. Mass and number dust concentrations at industrial and office workplaces. J Aerosol Sci. 2003;1:393-4.

19. Bakhsi MS, Zhao L, Smith R, Possmayer F, Petersen NO. Metal nanoparticle pollutants interfere with pulmonary surfactant function in vitro. Biophys J. 2008;94:855-68. 